\title{
HUBUNGAN PANJANG BOBOT DAN MORTALITAS LOBSTER PASIR (Panulirus homarus LINNAEUS 1758) DI PERAIRAN KOTA BENGKULU
}

\author{
Muhammad Natsir Kholis ${ }^{\mathrm{a}, *}$, Novita MZ ${ }^{\mathrm{b}}$ \\ ${ }^{a}$ Universitas Muara Bungo, Jl. Diponegoro No. 27, Jambi 37211, Indonesia \\ ${ }^{\mathrm{b}}$ Universitas Muhammadiyah Sukabumi, Jl. R. Syamsudin, S.H. No. 50, Cikole, Kota Sukabumi, Jawa Barat \\ 43113. Indonesia \\ *Koresponden penulis: kholis2336@gmail.com
}

\begin{abstract}
Abstrak
Lobster pasir (Panulirus homarus) merupakan salah satu komoditas yang memiliki banyak peminat sehingga memiliki kecenderungan mendapat tekanan penangkapan yang besar. Akibatnya, terjadi penurunan jumlah produksi dan ukuran tangkap. Hal ini juga diduga terjadi pada lobster pasir yang terdapat di perairan Bengkulu sehingga perlu dilakukan kajian mengenai biologinya. Tujuan dari penelitian ini adalah menganalisis hubungan panjang bobot dan mortalitas lobster pasir yang ditemukan di perairan Kota Bengkulu. Penelitian dilakukan terhadap 382 ekor lobster yang tertangkap dengan menggunakan jaring lobster. Hasil analisis menunjukkan bahwa ukuran rata-rata lobster yang tertangkap adalah 50-86 $\mathrm{mm}$ dengan lebih dari 70\% berada pada ukuran kurang dari $80 \mathrm{~mm}$. Adapun pola pertumbuhan lobster yang ditemukan adalah alometrik negatif. Laju mortalitas total lobster pasir adalah 1,66 dengan mortalitas alami dan penangkapan masing-masing 50\%.
\end{abstract}

Kata kunci: Hubungan panjang bobot, Lobster pasir, Mortalitas, Pertumbuhan

\begin{abstract}
Spiny lobster (Panulirus homarus) is one of the commodities that is in great demand so that it has a tendency to be under high fishing pressure. As a result, there is a decrease in the amount of production and catch size. This is thought to also occur in the spiny lobster found in Bengkulu City waters, so it is necessary to study its biology. The purpose of this research was to analyze the relationship between length and weight and mortality of spiny lobster found in Bengkulu City waters. The study was conducted on 382 lobsters caught using bottom nets. The results of the analysis showed that the average size of the lobster caught was $50-86 \mathrm{~mm}$ with more than $70 \%$ less than $80 \mathrm{~mm}$. The lobster growth pattern found was negative allometric. The total mortality of spiny lobster of sand lobster was 1,66 with natural and catch mortality of 50\% each.
\end{abstract}

Keywords: length-weight relationship, spiny lobster, mortality, growth

\section{PENDAHULUAN}

Salah satu hasil tangkapan nelayan non ikan yang paling populer saat ini di Indonesia adalah jenis lobster [1]. Menurut FAO [2], Indonesia merupakan salah satu penghasil lobster terbesar di Asia Tenggara. Terdapat setidaknya 6 dari 11 jenis Panulirus yang tersebar mulai dari pantai Barat dan pantai Timur Sumatera, pantai Utara dan Selatan Jawa (Palabuhanratu, Garut, Gunung Kidul, Cilacap dan Pacitan), Teluk Bone, Selatan Makasar, Laut Maluku, hingga Arafura [3]; [4].

Produksi lobster di beberapa daerah mengalami penurunan, seperti di Selatan Jawa khususnya perairan Yogyakarta yang mengalami penurunan produksi dari tahun 2001-2008 [5]; [6]. Selain jumlah produksi yang menurun, ukuran lobster yang tertangkap juga mengecil [6]. Hal ini disebabkan oleh adanya tekanan penangkapan sebagai akibat dari permintaan yang terus meningkat, baik dari pasar nasional maupun internasional. Adapun pasar internasional yang menjadi negara pengimpor lobster Indonesia adalah Taiwan, Tiongkok, Hongkong, Singapura, Australia, Malaysia, Thailand, Jepang, Korea Selatan, dan Vietnam [7]; [8]. Pada tahun 2020, permintaan pasar dunia untuk lobster mencapai 43.000 ton per tahun [9]. 
Bengkulu merupakan salah satu daerah penghasil lobster, khususnya lobster pasir (Panulirus homarus). Potensi lobster di perairan Kota Bengkulu yaitu sebesar 320 ton/tahun [10]. Namun belum banyak kajian yang dilakukan mengenai kondisi produksi lobster Kota Bengkulu, sehingga perlu dilakukan kajian untuk mengungkap indikasi adanya peningkatan tekanan penangkapan.

Menurut Zairion et al. [11], untuk menjamin keberlanjutan sumberdaya lobster di alam maupun keberlanjutan stok untuk masa depan adalah menjaga intensitas penangkapan di perairan. Syafrialdi et al. [12] menambahkan bahwa banyak alternatif untuk melestarikan sumberdaya perikanan, seperti: konservasi, budidaya, dan domestikasi. Kebijakan ini tentunya memerlukan dasar berupa kajian biologi yang meliputi pertumbuhan dan mortalitas biota di perairan.

Kajian pertumbuhan, khususnya pola pertumbuhan dari hubungan panjang bobot biota dapat menjadi infomasi dasar bagi pengembangan kebijakan pelestarian sumberdaya perikanan. Hal ini dikarenakan pertumbuhan merupakan fungsi dari kondisi

\section{Sumber dan Teknik Pengumpulan Data}

Metode yang digunakan pada penelitian ini adalah metode experimental fishing. Metode ini mengikuti kegiatan penangkapan lobster secara langsung dengan nelayan. Sumber data terdiri dari data primer dan didukung data sekunder. Data primer yaitu data perairan, baik fisika, kimia, dan biologi, serta tekanan karena aktivitas manusia [13]; [14]; [15]. Informasi ini sangat berguna dalam pengelolaan penangkapan, seperti menentukan jumlah tangkap boleh, ukuran tangkap, musim, dan selektivitas alat tangkap [16].

Pentingnya informasi mengenai biologi lobster dan laju mortalitas mendorong dilakukan kegiatan penelitian ini. Penelitian bertujuan untuk menganalisis hubungan panjang bobot dan mortalitas lobster pasir (Panulirus homarus) di perairan Kota Bengkulu yang ditangkap menggunakan jaring lobster (bottom gillnet).

\section{METODE}

\section{Waktu dan Tempat}

Penelitian dilaksanakan di Pantai Malabero dan Pantai Zakat yang terletak di Kecamatan Teluk Segara, Kota Bengkulu, Provinsi Bengkulu (Gambar 1). Survei dan penangkapan lobster dilakukan sebanyak 42 trip bulan April -Juni 2020.

ukuran panjang karapas, panjang tubuh, berat/bobot (Gambar 2) dan data morfologi. Sedangkan data sekunder didapatkan melalui data statistik dinas perikanan, UPTD, perguruan tinggi dan sumber lainnya. 


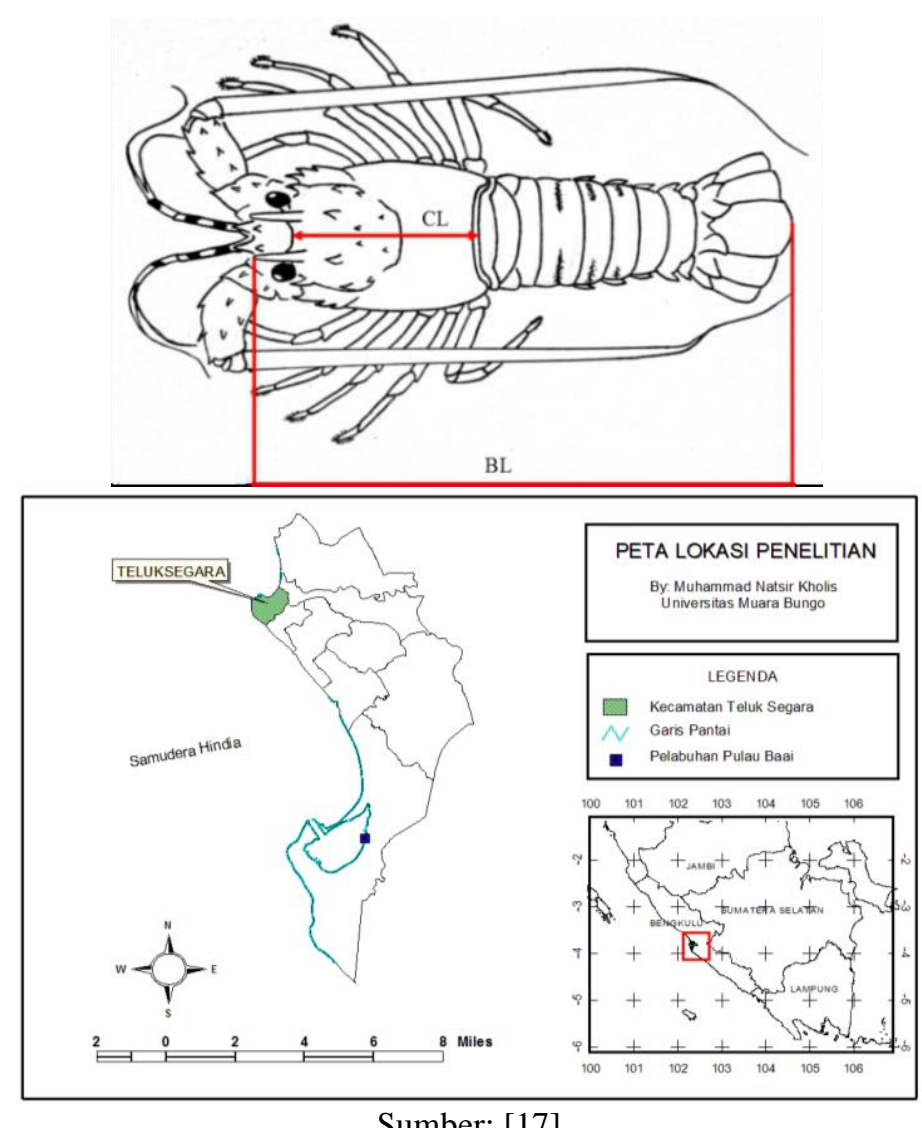

Gambar 1. Peta Lokasi Penelitian

Gambar 2. Teknik Mengukur Panjang Karapas (CL) dan Panjang Tubuh (BL) Lobster

\section{Analisis Data}

1. Sebaran frekuensi panjang karapas

Sebaran frekuensi panjang karapas dianalisis berdasarkan selang kelas, nilai tengah selang kelas, dan frekuensi lobster pasir di setiap kelas ukuran panjang karapas. Sebaran frekuensi panjang karapas yang diperoleh tersaji dalam bentuk histogram yang menampilkan jumlah lobster pada setiap selang kelas [17].

2. Hubungan panjang karapas dengan bobot

Hubungan panjang karapas dengan bobot lobster dicari melalui persamaan berikut [18] :

$$
W=a \cdot C L^{b}
$$

Bobot lobster diwakili oleh W dan memiliki satuan gram. CL adalah panjang karapas lobster dalam satuan milimeter. Konstanta diwakili oleh a, dan b merupakan nilai eksponensial. Nilai konstanta a dan b diperoleh dengan melinearkan persamaan di atas, menjadi:

$$
\log \mathrm{W}=\log \mathrm{a}+\mathrm{b} \cdot \log \mathrm{L}
$$

Hubungan panjang karapas dengan bobot dapat dilihat dari nilai b yang diperoleh. Hubungan panjang karapas dengan bobot bersifat isometrik jika nilai $b=3$. Selain itu, hubungan panjang karapas dengan bobot bersifat alometrik jika nilai $b \neq 3$. Pertumbuhan alometrik dapat bersifat positif $(b>3)$ maupun negatif $(b<3)$.

3. Laju Mortalitas Alami

Laju mortalitas alami (M) diduga dengan menggunakan rumus [18]; [19], yaitu :

$$
\begin{aligned}
\ln M=-0,0152 & -0,2790 \\
& * \ln L_{\infty}+0,6543 \\
& * \ln K+0,4630 * \ln T
\end{aligned}
$$

$$
\begin{gathered}
\log K=\frac{0,3922-0,2752\left(\log L_{\infty}\right)-\log \left(-t_{0}\right)}{L_{\infty}=\frac{a^{0,6543}}{1-b}}
\end{gathered}
$$


dimana :

$$
\begin{array}{ll}
a=\frac{\Sigma y_{i}-b \Sigma x_{i}}{n} & M=\text { laju mortalitas alami } \\
b=\frac{n \cdot \Sigma x_{i} y_{i}-\Sigma x_{i} . \Sigma y_{i}}{n \cdot \Sigma x_{i}^{2}-\left(\Sigma x_{i}\right)^{2}} & K=\text { panjang asimtotik } \\
& T
\end{array}
$$

= rata-rata suhu permukaan laut (spl) dalam setahun

$t_{0}=$ umur teoritis pada saat ikan panjang nol

$a=$ intersep

$b=$ koefisien regresi

$x_{i}=$ panjang ikan umur $n$

$y_{i}=$ panjang ikan umur $n+1$

\section{Laju Mortalitas Total}

Mortalitas total akan diduga dengan persamaan yang dikemukakan oleh [19]; [20] yaitu :

$$
\begin{aligned}
& =\frac{0,3922-0,2752\left(\log L_{\infty}\right)-\log \left(-t_{0}\right)}{0,6543} \\
& L_{\infty}=\frac{a}{1-b} \\
& a=\frac{\Sigma y_{i}-b \Sigma x_{i}}{n} \\
& b=\frac{n \cdot \Sigma x_{i} y_{i}-\Sigma x_{i} \cdot \Sigma y_{i}}{n \cdot \Sigma x_{i}^{2}-\left(\Sigma x_{i}\right)^{2}} \\
& \ln M=-0,0152-0,2790 \\
& * \ln L_{\infty}+0,6543 \\
& * \ln K+0,4630 * \ln T
\end{aligned}
$$$$
\log K
$$$$
Z=K\left[\frac{L_{\infty}-\bar{L}}{\bar{L}-L^{\prime}}\right]
$$

dimana:

$Z=$ laju mortalitas total

$M=$ laju mortalitas alami

Lo = panjang asimtotik

$K=$ koefisien laju pertumbuhan

HASIL DAN PEMBAHASAN

\section{Sebaran Frekuensi Panjang}

Hasil penangkapan selama bulan April-Juni menunjukkan bahwa terdapat sebanyak 382 lobster tertangkap dengan ukuran panjang berkisar antara 50-85 mm. Ukuran paling banyak tertangkap adalah 78,882,3 $\mathrm{mm}$ disusul dengan 82,4-85,9 $\mathrm{mm}$, sementara itu ukuran 53,6-67,9 mm tidak
$\bar{L}=$ panjang rata-rata ikan tertangkap

$L^{\prime}=$ batas panjang ikan terkecil tertangkap

$t_{0}=u m u r$ teoritis pada saat ikan panjang nol

$a=$ intersept

$b=$ koefisien regresi

$x_{i}=$ panjang ikan umur $n$

$y_{i}=$ panjang ikan umur $n+1$

5. Mortalitas Penangkapan

Laju mortalitas penangkapan dihitung dengan menggunakan rumus [19]; [20] sebagai berikut Mortalitas penangkapan (F) diduga dengan persamaan $\mathrm{Z}=\mathrm{F}+\mathrm{M}$ sehingga laju mortalitas penangkapan dihitung dengan menggunakan rumus sebagai berikut:

Dimana:

$$
F=Z-M
$$

$F=$ laju mortalitas penangkapan

$Z=$ laju mortalitas total

$M=$ laju mortalitas alami ditemukan (Gambar 3). Adapun bobot lobster tertangkap berkisar antara 105-205 g.

Jika dibandingkan dengan penelitian lainnya, diketahui bahwa panjang lobster yang tertangkap di perairan Bengkulu relatif rendah. Di perairan Aceh Utara disebutkan bahwa ukuran panjang lobster pasir yang tertangkap berkisar antara 60-130 mm [21]. Sementara itu, 250 lobster yang tertangkap di perairan Sri Lanka memiliki panjang berkisar antara 111$278 \mathrm{~mm}$ [22]. Ukuran tangkap yang kecil dapat mengindikasikan bahwa telah terjadi 
penangkapan lebih, kualitas lingkungan perairan kurang baik, atau alat tangkap yang digunakan tidak selektif.

PERMEN-KP No 56 tahun 2016 mengenai ukuran legal tangkap lobster menyatakan bahwa lobster yang layak tangkap harus memiliki ukuran lebih dari $8 \mathrm{~cm}$, karena ukuran ini merupakan ukuran dimana lobster sudah memijah. Berdasarkan kondisi tersebut dapat dikatakan bahwa hanya 37,7\% tangkapan yang termasuk layak tangkap

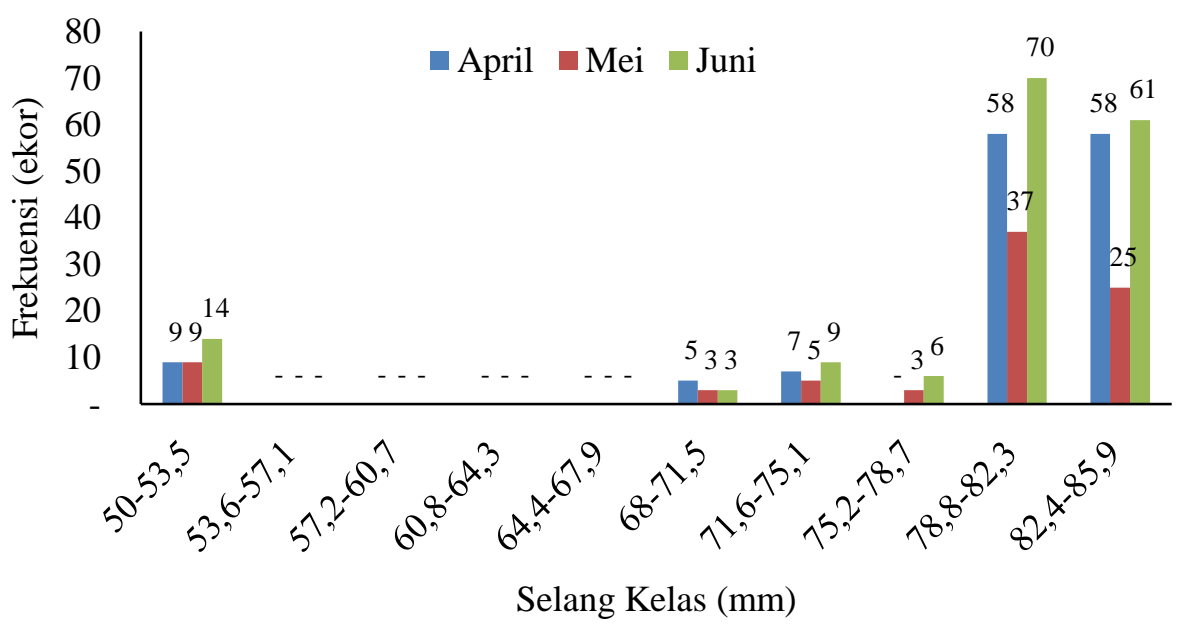

Gambar 3. Sebaran frekuensi panjang lobster pasir di Perairan Bengkulu

\section{Hubungan Panjang Bobot}

Hubungan panjang bobot merupakan hubungan non-linear yang dapat dikonversi menjadi hubungan linear antara log panjang dan $\log$ bobot dengan formula $\log \mathrm{W}=\mathrm{a}+\mathrm{b}$ * Log L. Nilai b merupakan koefisien yang menunjukkan pola pertumbuhan lobster, yakni isometrik, alometrik negatif, atau alometrik positif.
Hasil analisis menunjukkan bahwa panjang bobot lobster pasir yang ditemukan di perairan Bengkulu memiliki persamaan Log $\mathrm{W}$ $=0,8484 \log \mathrm{L}+0,6019$ (Gambar 4). Hasil uji $\mathrm{t}$ menunjukkan bahwa $\mathrm{b}$ sebesar 0,8484 tidak sama dengan 3 ( $p>0,05)$, artinya pertumbuhan lobster pasir tergolong alometrik negatif, dimana pertambahan panjang lebih dominan dibandingkan dengan pertambahan bobot. 


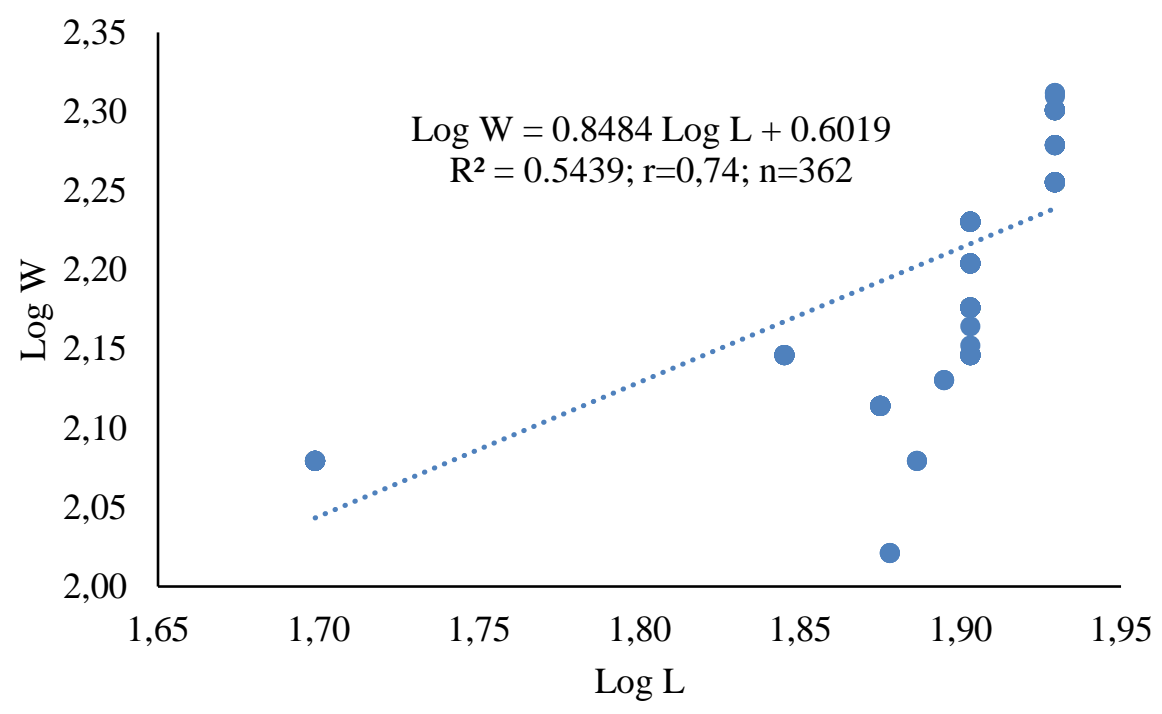

Gambar 4. Hubungan panjang dan bobot lobster pasir di Perairan Bengkulu

Jika dibandingkan dengan beberapa penelitian terdahulu, diketahui bahwa lobster pasir memiliki pola pertumbuhan yang berbeda. Suman dan Subani [23] menyebutkan bahwa lobster yang terdapat di Aceh Barat memiliki pola pertumbuhan alometrik negatif, sementara di perairan Selat Bali, lobster yang ditemukan memiliki pola pertumbuhan alometrik positif. Nuraini dan Subiono [24] dan Junaidi et al. [25] menemukan bahwa lobster yang ditemukan di Pangandaran dan Lombok memiliki pola pertumbuhan alometrik negatif. Sementara itu, Sparre dan Venema [19] menemukan bahwa lobster memiliki pertumbuhan isometrik dan alometrik negatif. Perbedaan pola pertumbuhan lobster yang ditemukan dapat disebabkan oleh beberapa faktor, seperti jenis kelamin, ketersediaan makanan di alam, persaingan dan pemangsaan, umur, stadia kematangan gonad, dan kualitas perairan.

Hasil korelasi panjang dan bobot menunjukkan nilai korelasi sebesar 0,74, artinya terdapat hubungan yang erat antara panjang dan bobot, dimana pertambahan panjang akan mempengaruhi pertambahan bobotnya. Adapun nilai koefisien determinasi adalah 0,5439 atau 54,39\%, artinya keragaman panjang mampu menjelaskan keragaman bobot sebesar $54,39 \%$.

\section{Mortalitas}

Mortalitas merupakan kematian yang dapat disebabkan oleh faktor alami, seperti penyakit, kompetisi, kanibalisme, umur tua, predator, pencemaran, dan bencana alam ataupun akibat penangkapan. Mortalitas dapat diduga dengan pendekatan jumlah populasi atau panjang rata-rata biota tertangkap dalam waktu tertentu.

Hasil analisis menunjukkan bahwa nilai kematian total dari lobster di Perairan Bengkulu adalah 1,66 per tahun. Adapun kematian alami dari lobster adalah 0,84 dengan kematian akibat penangkapan mencapai 0,82 per tahun. Oleh karena itu, laju eksploitasisnya mencapai 0,49 per tahun. Hasil analisis menunjukkan kematian alami dan penangkapan masing-masing 50\%. Hal ini mengindikasikan bahwa tidak ada irisan antara lobster yang mati alami dengan mati tertangkap, sehingga dapat dikatakan bahwa alat tangkap yang digunakan tidak selektif. Sementara itu, dari laju eksploitasi menunjukkan bahwa lobster belum mengalami kondisi tangkap lebih.

Hasil penelitian terdahulu menunjukkan bahwa mortalitas total lobster di Perairan Cilacap Jawa Tengah tidak berbeda dibandingkan dengan Bengkulu, yakni 1,6 per tahun, namun kematian alami hanya sebesar 0,69 per tahun. Akibatnya, tingkat eksploitasi 
mencapai 0,57per tahun, yang berarti sudah mengalami tangkap lebih [26].

\section{KESIMPULAN}

Lobster pasir ( $P$. homarus) yang tertangkap di Perairan Bengkulu masih belum layak tangkap dilihat dari panjang lobster yang tertangkap. Adapun hubungan panjang dan bobotnya menunjukkan bahwa pola pertumbuhan lobster pasir adalah alometrik negatif. Mortalitas alami dan penangkapan masing-masing sebesar $50 \%$. Berdasarkan parameter biologi yang diamati selama penelitian mengindikasikan bahwa alat tangkap yang digunakan tidak selektif dan diduga perairan memiliki kualitas yang kurang mendukung untuk pertumbuhan lobster pasir.

\section{DAFTAR PUSTAKA}

[1] Puspito, G. 2009. Perangkap Non Ikan. Bogor: Departemen Pemanfaatan Sumberdaya Perikanan, FPIK-IPB.

[2] [FAO]. Food and Agriculture Organization of the United Nations. 2011-2012. Cultured Aquatic Species Information Programme. Panulirus homarus. Text by Jones, C. In: FAO Fisheries and Aquaculture Department. Rome.

http://www.fao.org/fishery/culturedspec ies/Panulirus_homarus/en

[3] Mahdiana, A., dan S.P. Laurensia. 2011. Status perikanan lobster (Panulirus spp,) di perairan Kabupaten Cilacap. Sains Akuatik,13 (2): 52-57.

[4] Pratiwi, R. (2018). Keanekaragaman dan potensi lobster (Malacostraca: Palinuridae) di Pantai Pameungpeuk, Garut Selatan, Jawa Barat. Majalah Ilmiah Biologi BIOSFERA: A Scientific Journal, 35(1), 10-22.

[5] [P4KSI]. Pusat Penelitian Pengelolaan Perikanan dan Konservasi Sumberdaya Ikan. 2012. Developing New Assessment and Policy Framework for Indonesia's Marine Fisheries, Including the Control and Management of Illegal,
Unregulated and Unreported Fishing. Laporan Teknis: $111 \mathrm{p}$.

[6] Hargiyatno, I.T., F. Satria, A.P. Prasetyo, dan M. Fauzi. 2013. Hubungan panjang-berat dan faktor kondisi lobster pasir (Panulirus homarus) di perairan Yogyakarta dan Pacitan. BAWAL, 5(1):41-48.

[7] Rahmah, L.N.A. 2016. Analisis aliran perdagangan dan strategi pengembangan ekspor lobster Indonesia. [Tesis]. Bogor (ID): Institut Pertanian Bogor.

[8] Lidwina, A. 2019. Siapa Pasar Ekspor Lobster Terbesar Indonesia? Tersedia pada

https://databoks.katadata.co.id/datapubl ish/2019/12/23/siapa-pasar-eksporlobster-terbesar-indonesia. Diakses pada 30 Oktober 2021, 21.00 WIB.

[9] Rochim, A. 2020. Polemik ekspor benih lobster, potensi capai Rp 400 Triliun per tahun. Tersedia pada https://ekbis.sindonews.com/read/1035 24/34/polemik-ekspor-benih-lobsterpotensi-capai-rp400-triliun-per-tahun1594904868. Diakses pada 31 Oktober 2021, 14.50 WIB.

[10] [Sekjen KKP]. Sekretaris Jendral Kementerian Kelautan dan Perikanan. 2012. Validasi Data Produksi KP Semester 1 Tahun 2019. Laporan Pusat Data Statistik dan Informasi. Jakarta, 14 Hlm.

[11] Zairion, Z., N. Islamiati, Y. Wardiatno, A. Mashar, R.A. Wahyudin, dan A.A. Hakim. (2018). Dinamika Populasi Lobster Pasir (Panulirus homarus Linnaeus, 1758) di Perairan Palabuhanratu, Jawa Barat. Jurnal Penelitian Perikanan Indonesia, 23(3): 215-226.

[12] Syafrialdi, Dahelmi, D.I. Roesma, dan H. Syandri. 2020. Length-weight relationship and condition factor of twospot catfish (Mystus nigriceps [Valenciennes, 1840]) ( Pisces, Bagridae), from Kampar Kanan River and Kampar Kiri River in Indonesia. Pakistan Journal of Biology Sciences, 23 (12): 1636-1642. 
[13] Courtney Y., J. Courtney, dan M. Courtney. 2014. Improving weightlength relationship in fish to provide more accurate bioindicators of ecosystem condition. J. Aquatic Science and Technology. 2(2): 41-51.

[14] Froese, R. 2006. Cube law, condition factor, and weight-length relationship: history, meta-analysis, and recommendations. J. Appl. Ichthyol. 22: 241-253.

[15] Rosli, N.A.M, dan M.M. Isa. 2012. Length-weight and Length-length relationship of longnousted catfish, Plicofollis argyropleuron (Valenciennes 1840) in the Northern Part of Peninsular Malaysia. Journal Tropical Life Sciences Research. 23(2): 59-65.

[16] Nurhayati, Fauziyah, dan S.M. Bernas. 2016. Hubungan panjang-berat dan pola pertumbuhan ikan di Muara Sungai Musi Kecamatan Banyuasin Sumatera Selatan. Maspari Journal, 8(2):111-118.

[17] Kintani, N. I., I. Setyobudiandi, dan Y. Wardiatno. 2020. Biologi reproduksi lobster pasir (Panulirus Homarus Linnaeus, 1758) di Teluk Palabuhanratu. Habitus Aquatica, 1(1): 1-15.

[18] Pauly, D. (1984). Fish population dynamics in tropical waters: A manual for use with programmable calculators. ICLARM Studies and Reviews $8.325 \mathrm{p}$

[19] Sparre, P., dan S.C. Venema. 1998. Introduction to tropical fish stock assessment, Part 1. Manual. FAO Fisheries Technical Paper. No. 306.1, Rev. 2. Rome, FAO.

[20] Beverton, R.J., dan S.J. Holt. 1957. On the dynamics of exploited fish populations. Gt. Britain, Fishery Invest.,Ser. II. Vol. XIX. 533 pp.

[21] Irfannur, R.I. Wahju, dan M. Riyanto. 2017. Komposisi hasil tangkapan dan ukuran lobster dengan jaring insang di Perairan Kabupaten Aceh Jaya. Albacore, I(2):211-223.

[22] Senevirathna, D., T. Gamage, dan D. Munasinghe. 2014. Length-weight relationship of spiny lobster, Panulirus homarus population inhabiting Southern Coastal Region of Sri Lanka.
International Journal of Science, Environment and Technology, 3(2): 607-614.

[23] Suman, A., dan W. Subani. 1993. Pengusahaan sumberdaya udang karang di perairan Aceh Barat. Jurnal Penelitian Perikanan Laut, 8: 84-90.

[24] Nuraini, S., dan B. Sumiono. 2008. Parameter Biologi Udang Barong di Pantai Selatan Pengandaran, Jawa Barat. Prosiding Seminar Nasional Tahun V Hasil Penelitian Perikanan dan Kelautan UGM. Jogjakarta.

[25] Junaidi. M., N. Cokrowati, dan Z. Abidin. 2010. Aspek reproduksi lobster (Panulirus sp.) di Perairan Teluk Ekas Pulau Lombok. Jurnal Kelautan. 3(1): 29-35.

[26] Bakhtiar, N.M., A. Solichin, dan S.W. Saputra. 2013. Pertumbuhan dan laju mortalitas lobster batu hijau (Panulirus homarus) di Perairan Cilacap Jawa Tengah. Diponegoro Journal of Maquares, 2(4): 1-10. 